\title{
LEAD AND CADMIUM CONTENT OF BRAZILIAN BEERS ${ }^{1}$
}

\author{
Lucia Maria Valente SOARES ${ }^{2 *}$, Adriana Maria Monteiro de MORAES ${ }^{2}$
}

\section{SUMMARY}

The elements called heavy metals when ingested are not completely eliminated from animal bodies and are responsible for chronic and acute intoxications. Sixty-three samples of beer, produced in the states of São Paulo, Paraná, Rio de Janeiro, Rio Grande do Sul, Minas Gerais, and Pará, were analysed for lead and cadmium content by atomic absorption spectrometry with graphite furnace atomization and Zeeman correction. The concentrations of $\mathrm{Pb}$ and $\mathrm{Cd}$ of dark differed significantly from light beers, being higher in the former. No significant difference was found between the beers produced in predominantly rural areas and the ones produced in industrialized areas. The concentrations of lead and cadmium in all samples were bellow the maximum accepted by present Brazilian regulations and ranged from not detected to $290 \mu \mathrm{gPb} / \mathrm{L}$ and from not detected to $14.3 \mu \mathrm{gCd} / \mathrm{L}$. The average concentrations were $37 \mu \mathrm{gPb} / \mathrm{L}$ and $1.6 \mu \mathrm{gCd} / \mathrm{L}$.

Keywords: lead; cadmium; beer.

\section{RESUMO}

TEORES DE CHUMBO E CÁDMIO EM CERVEJAS BRASILEIRAS. Os elementos chamados de metais pesados quando ingeridos não são completamente eliminados dos organismos animais e são responsáveis por intoxicações crônicas e agudas. Sessenta e duas amostras de cerveja, produzida nos estados de São Paulo, Paraná, Rio de Janeiro, Rio Grande do Sul, Minas Gerais e Pará, foram analisadas para chumbo e cádmio por espectrometria de absorção atômica com atomização em forno de grafite e corretor de Zeeman. As concentrações $\mathrm{de} \mathrm{Pb}$ and $\mathrm{Cd}$ nas cervejas escuras foram mais elevadas e diferiram significativamente das concentrações em cervejas claras. Nenhuma diferença significativa foi encentrada nas concentrações destes elementos em cervejas produzidas em áreas predominantemente rurais ou em áreas industrializadas, e ainda em cervejas embaladas em latas de alumínio ou em garrafas de vidro. As concentrações de chumbo e cádmio estavam abaixo do máximo aceito pela regulamentação brasileira atual e variaram de não detectado a $290 \mu \mathrm{gPb} / \mathrm{L}$ e de não detectado a $14.3 \mu \mathrm{gCd} / \mathrm{L}$. As concentrações médias foram $38 \mu \mathrm{gPb} / \mathrm{L}$ e $1.6 \mu \mathrm{gCd} / \mathrm{L}$.

Palavras-chave: chumbo; cádmio; cerveja.

\section{1 - INTRODUCTION}

An important aspect of guaranteeing the wholesomeness of our food supply is to watch for the presence of the so called heavy metals. Such elements, once absorbed into our body, are not completely eliminated and cause undesirable metabolic disturbances reducing work capabilities and life spans of affected individuals. Toxic elements are found in various types of agricultural chemicals, pigments for ceramics and enamels, and industrial wastes [11]. Atmosphere, watercourses and the seas are the final destination of all kinds of wastes and the presence of heavy metals in wastes increases the level of toxic elements in our environment. Even underground water is affected.

The presence of heavy metals in foods and beverages, except for accidents or criminal actions, reflects the environment. The main component in beverages is water. As a consequence, the concentration of heavy metals in beverages may be related to the purity of the water used. Surveying of foods and beverages for heavy metals, besides indicating the existence or not of failures or accidental contamination during processing, storage or transportation of foods, also indicates environmental contamination. In addition it may serve as a reference in future evaluations of the same kind.

\footnotetext{
1. Recebido para publicação em 22/06/2002. Aceito para publicação em 22/11/2002 (000869).

2. Department of Food Science, State University of Campinas, C.P. 6121 13081-970 Campinas, SP, Brazil.

* A quem a correspondência deve ser enviada.
}

The symptoms of lead poisoning have been described in comprehensive reviews [10,11] and include damage to the haemoglobin production, the kidneys and to the nervous and the gastric systems. Acute cadmium poisoning causes nausea, abdominal pain and headaches. Diarrhoea and shock may occur. Prolonged ingestion damages the kidneys and causes the bones to break easily. A cadmium poisoning incident has been recorded in the late sixties under the name of Itai-Itai connected to a population group located in Japan. Teratogenic effects have also been reported.

Beer is one of the most consumed beverages in Brazil. Yet, the annual per capita intake of beer was only $6.4 \mathrm{~L}$ in 1996, according to the INSTITUTO BRASILEIRO DE GEOGRAFIA E ESTATISTICA [7]. Having in mind that the male population is the main consumer of the beverage and that children should be excluded from the any ingestion calculation, it can be derived from the same population data [7] that the average daily intake of beer by Brazilian adult men was $51 \mathrm{~mL} /$ per capita in 1996 . It follows that in spite of the popularity beer enjoys in Brazil its intake can be considered actually low and contrasts with that of other countries such as Germany where adult males drank 516mL/day in 1991 [9].

Information on the levels of cadmium and lead in Brazilian beers is scant and only one published report can be found presently. MATSUSHIGE and OLIVEIRA [8] analysed 18 samples of Brazilian beers for several natural constitutive microelements $(\mathrm{Co}, \mathrm{Cr}, \mathrm{Cu}, \mathrm{Fe}$ and $\mathrm{Zn}$ ) and for lead. The present work examined beers produced in different areas of the country in order to 
obtain information of the situation of the beverage in terms of its lead and cadmium content.

\section{2 - MATERIAL AND METHODS}

\section{1 - Sampling and sample preparation}

Beers, in glass bottles or cans, were acquired in markets and shops of 6 states (São Paulo, Paraná, Rio de Janeiro, Rio Grande do Sul, Minas Gerais, Pará). The beers were produced in plants located at the states mentioned. The samples were kept at room temperature until analysis when they were opened, poured into a glass beaker and degassed in an ultrasonic bath.

For lead determination 1 part of beer was diluted with 3 parts of 5\% solution of Triton-X-100 (J.T. Baker) containing $0.2 \% \mathrm{HNO}_{3}$ (Suprapur, Merck). For cadmium determination 1 part beer was diluted with 4 parts of $5 \%$ solution of Triton-X-100 (J.T. Baker) containing 0.2\% $\mathrm{HNO}_{3}$ (Suprapur, Merck). All solutions and blanks used ultra pure water with resistivity of 18 megaohm (MilliQ plus, Millipore).

\section{2 - Standards}

The parent standards for lead and cadmium were prepared by diluting an ampoule of atomic absorption standard with ultra pure water (Merck or Carlo Erba) to $1 \mathrm{~L}$. Intermediate dilutions and working standards were prepared every day by diluting the parent standard with $0.2 \% \mathrm{HNO}_{3}$ (Suprapur, Merck). The working standards concentrations were $40 \mu \mathrm{g} / \mathrm{L}$ and $10 \mu \mathrm{g} / \mathrm{L}$ for $\mathrm{Pb}$ and $\mathrm{Cd}$, respectively. The calibration curve for $\mathrm{Pb}$ ranged from 5 to $40 \mu \mathrm{g} / \mathrm{L}$ and the one for $\mathrm{Cd}$ ranged from 1 to $5 \mu \mathrm{g} / \mathrm{L}$.

\section{3 - Glassware and plasticware cleanup}

All containers in contact with samples and standards were washed with water and detergent and left soaking in a $10 \%$ nitric acid solution for 24 hours. After soaking they were well rinsed 3 times with ultra pure water and allowed to dry in a place well protected from dust.

\section{4 - Determination of lead and cadmium concentrations in beers}

Lead and cadmium were determined in an atomic absorption spectrofotometer (model 5100 PC Zeeman, Perkin-Elmer, Connecticut, U.S.A.), with graphite furnace module (model HGA 600), automatic sampler (model HS 60), lead EDL lamp, Cd hollow cathode lamp, and nitrogen as inert gas (internal gas flow). The main resonance lines were used for $\mathrm{Pb}(283.3 \mathrm{~nm})$ and $\mathrm{Cd}(228.8 \mathrm{~nm})$. The graphite furnace programs for $\mathrm{Pb}$ and $\mathrm{Cd}$ were as shown in Table 1 and a 4\% solution of monobasic ammonium fostate (Merck) was used as a modifier.

\section{5 - Analytical quality control}

A calibration curve was established as well as the characteristic mass for the element being determined before reading each series of samples. The conditions were considered adequate if the characteristic masses for both elements were within $20 \%$ of the value stated by instrument maker (0.5 and 12.0 picograms for $\mathrm{Cd}$ and $\mathrm{Pb}$, respectively). The samples were analyzed in duplicates and each duplicate was fired twice. A recovery test and a re-slope of the calibration curve were conducted together with each set of 3 or 4 samples. Calibration blanks and reagents blanks were fired three times for each set of samples being analyzed.

TABLE 1. Graphite furnace programs for for $\mathrm{Pb}$ and $\mathrm{Cd}$ determinations.

\begin{tabular}{lrrccc}
\hline \multirow{2}{*}{ Step } & \multicolumn{2}{c}{ Temp. $\left({ }^{\circ} \mathrm{C}\right)$} & \multicolumn{2}{c}{ Time $(\mathrm{sec})$} & Internal gas flow \\
& $\mathrm{Pb}$ & $\mathrm{Cd}$ & Ramp & Hold & $(\mathrm{mL} / \mathrm{min})$ \\
\hline Drying & 120 & 120 & 1 & 50 & 300 \\
Ashing & 400 & 400 & 1 & 40 & 300 \\
Cooling & 20 & 20 & 1 & 15 & 300 \\
Atomization & 2000 & 1650 & 0 & 7 & 0 \\
Cleaning & 2600 & 2600 & 1 & 5 & 300 \\
Cooling & 20 & 20 & 1 & 60 & 300 \\
\hline
\end{tabular}

The following certified reference materials were obtained from the National Institute of Standards and Technology (NIST, Gaithersburg, U.S.A.) analytical quality control purposes: Apple Leaves SRM 1515 and Peach Leaves SRM 1547. The samples were digested with nitric acid (Suprapur, Merck) and allowed to dry. The residue was dissolved with $0,2 \% \mathrm{HNO}_{3}$ (Suprapur, Merck) and the amounts of $\mathrm{Cd}$ and $\mathrm{Pb}$ determined as described for the samples and standards. Reagent blanks were prepared the same way. The results were considered adequate if they fell within 1.5 of the standard deviation stated in the certified results.

\section{6 - Statistical analysis}

A two-tailed t-test was used to verify the significance of the differences between groups of beer samples.

\section{3 - RESULTS AND DISCUSSION}

Sixty-three samples of beer $(n=63)$ from breweries located at 20 districts in 6 Brazilian states (Minas Gerais, Pará, Paraná, Rio de Janeiro, Rio Grande do Sul and São Paulo) were analysed for $\mathrm{Cd}$ and $\mathrm{Pb}$. Beers were prepared by 8 different processes. The light beers included unspecified light types plus Pilsen, draft, and nonalcoholic types. The dark ones included Malzbier, München, and Bock types besides the regular dark. Samples from 22 brands were collected belonging to 8 beer-making companies (Table 2).

The results of the determinations of $\mathrm{Pb}$ and $\mathrm{Cd}$ in the beer samples (Table 2) were corrected for the recovery test conducted within the series of samples being analysed. The average recovery for lead was $91 \%(n=16)$ and for cadmium was $76 \%(n=16)$. As part of the analytical quality control two certified reference materials were analysed (Table 3). 
TABLE 2. Lead and cadmium content of Brazilian beers.

\begin{tabular}{|c|c|c|c|c|c|c|}
\hline Company & Brand & Plant location* & Type & Packaging & $\mathrm{Pb}(\mu \mathrm{g} / \mathrm{L})$ & $\mathrm{Cd}(\mu \mathrm{g} / \mathrm{L})$ \\
\hline \multirow[t]{27}{*}{ A } & $\mathrm{A}$ & rural & dark & $\mathrm{ac}$ & 211 & 1.7 \\
\hline & A & industrial & dark & $\mathrm{gb}$ & 41 & 5.0 \\
\hline & A & rural & light & $\mathrm{ac}$ & 31 & 3.4 \\
\hline & A & rural & light & $\mathrm{gb}$ & 47 & 2.8 \\
\hline & A & rural & light & gb & 1 & 0.5 \\
\hline & A & rural & light & gb & 9 & 0.4 \\
\hline & A & rural & light & gb & nd & 0.1 \\
\hline & A & rural & light & gb & nd & nd \\
\hline & A & rural & dark & gb & 19 & 9.6 \\
\hline & A & rural & dark & $\mathrm{gb}$ & 10 & 0.6 \\
\hline & 7 & industrial & light & $\mathrm{gb}$ & 74 & 2.8 \\
\hline & A & rural & light & $\mathrm{gb}$ & 26 & 1.1 \\
\hline & A & industrial & dark & $\mathrm{gb}$ & 19 & 0.1 \\
\hline & 2 & rural & light & $\mathrm{gb}$ & 4 & 0.2 \\
\hline & 2 & rural & light & $\mathrm{gb}$ & 46 & nd \\
\hline & 6 & rural & light & $\mathrm{gb}$ & 22 & 0.2 \\
\hline & 6 & rural & light & $\mathrm{gb}$ & 65 & nd \\
\hline & 6 & rural & nonalcoholic & $\mathrm{ac}$ & nd & nd \\
\hline & 11 & industrial & nonalcoholic & $\mathrm{gb}$ & nd & nd \\
\hline & 11 & rural & nonalcoholic & $\mathrm{ac}$ & nd & 0.3 \\
\hline & 11 & rural & nonalcoholic & $\mathrm{gb}$ & 46 & nd \\
\hline & 1 & industrial & light & $\mathrm{gb}$ & nd & 0.7 \\
\hline & 1 & rural & light & ac & 20 & nd \\
\hline & 3 & rural & light & ac & 32 & nd \\
\hline & 3 & rural & light & $\mathrm{gb}$ & nd & 0.5 \\
\hline & 14 & rural & dark & $\mathrm{gb}$ & 22 & 13.6 \\
\hline & 15 & rural & light & gb & 26 & 1.6 \\
\hline \multirow[t]{3}{*}{ B } & 12 & rural & dark & ac & 77 & 1.9 \\
\hline & 16 & rural & light & $\mathrm{ac}$ & 19 & nd \\
\hline & 16 & rural & light & $\mathrm{gb}$ & 28 & nd \\
\hline \multirow[t]{13}{*}{$\mathrm{C}$} & C & industrial & light & ac & 260 & 1.7 \\
\hline & $\mathrm{C}$ & industrial & light & $\mathrm{gb}$ & 39 & 14.3 \\
\hline & $\mathrm{C}$ & industrial & light & gb & 14 & nd \\
\hline & $\mathrm{C}$ & rural & light & $\mathrm{gb}$ & 26 & nd \\
\hline & $\mathrm{C}$ & industrial & light & $\mathrm{gb}$ & 22 & 0.6 \\
\hline & $\mathrm{C}$ & rural & light & $\mathrm{gb}$ & nd & 1.1 \\
\hline & $\mathrm{C}$ & industrial & light & $\mathrm{gb}$ & nd & 1.9 \\
\hline & C & industrial & dark & ac & 27 & 3.4 \\
\hline & $\mathrm{C}$ & industrial & dark & gb & 115 & 1.6 \\
\hline & 18 & industrial & light & ac & 26 & 2.8 \\
\hline & 4 & rural & dark & gb & 160 & 3.6 \\
\hline & 4 & industrial & dark & $\mathrm{gb}$ & 18 & 1.4 \\
\hline & 5 & industrial & light & $\mathrm{gb}$ & nd & nd \\
\hline \multirow[t]{3}{*}{ D } & D & industrial & light & $\mathrm{ac}$ & 14 & 1.5 \\
\hline & D & industrial & dark & $\mathrm{ac}$ & 35 & 4.8 \\
\hline & D & rural & light & $\mathrm{gb}$ & 30 & nd \\
\hline
\end{tabular}

* rural - plant located either in a predominantly rural area or small town; industrialized - plant located in an industrialized area. 
TABLE 2. Lead and cadmium content of Brazilian beers (continued).

\begin{tabular}{|c|c|c|c|c|c|c|}
\hline $\begin{array}{l}\text { Company } \\
(\mu \mathrm{g} / \mathrm{L})\end{array}$ & Brand & Plant location* & Type & Packaging & $\mathrm{Pb}(\mu \mathrm{g} / \mathrm{L})$ & $\mathrm{Cd}$ \\
\hline & $\mathrm{D}$ & rural & light & $\mathrm{gb}$ & nd & nd \\
\hline & D & industrial & dark & $\mathrm{gb}$ & 15 & nd \\
\hline & 13 & industrial & light & ac & 8 & 0.5 \\
\hline & 13 & industrial & light & ac & 35 & nd \\
\hline & 9 & industrial & light & ac & 35 & 0.8 \\
\hline & 8 & industrial & light & ac & 19 & nd \\
\hline & 8 & industrial & light & $\mathrm{gb}$ & nd & 0.2 \\
\hline & 8 & industrial & light & $\mathrm{gb}$ & 14 & nd \\
\hline \multirow[t]{3}{*}{$\mathrm{E}$} & $\mathrm{E}$ & rural & light & ac & 48 & 1.7 \\
\hline & $\mathrm{E}$ & rural & dark & ac & 23 & 1.5 \\
\hline & $\mathrm{E}$ & rural & dark & $\mathrm{gb}$ & 21 & 3.2 \\
\hline \multirow[t]{3}{*}{ F } & $\mathrm{F}$ & industrial & light & ac & 62 & 3.2 \\
\hline & $\mathrm{F}$ & industrial & light & $\mathrm{gb}$ & 290 & 3.2 \\
\hline & $\mathrm{F}$ & industrial & light & ac & 13 & nd \\
\hline \multirow[t]{2}{*}{$\mathrm{G}$} & 17 & rural & dark & $\mathrm{gb}$ & 19 & 0.1 \\
\hline & 17 & rural & dark & $\mathrm{gb}$ & 21 & 0.6 \\
\hline $\mathrm{H}$ & 10 & rural & light & $\mathrm{gb}$ & 58 & nd \\
\hline
\end{tabular}

* rural - plant located either in a predominantly rural area or small town; industrialized - plant located in an industrialized area gb - glass bottle, ac - aluminum can

The results are duplicates means and are corrected for recovery.

TABLE 3. Certified reference material (CRM) analytical results during the present work.

\begin{tabular}{|c|c|c|c|c|}
\hline \multirow[t]{2}{*}{ CRM } & \multicolumn{2}{|c|}{ Certified values $(\mu \mathrm{g} / \mathrm{g})$} & \multicolumn{2}{|c|}{ Values found $(\mu \mathrm{g} / \mathrm{g})$ * } \\
\hline & $\mathrm{Pb}$ & $\mathrm{Cd}$ & $\mathrm{Pb}$ & $\mathrm{Cd}$ \\
\hline Apple Leaves & $\begin{array}{l}0.470 \pm 0.024 \\
0.010 \pm 0.005\end{array}$ & $0.013 \pm 0.002$ & $0.448 \pm 0.031$ & \\
\hline NIST 1515 & & & & \\
\hline $\begin{array}{l}\text { Peach Leaves } \\
\text { NIST } 1547\end{array}$ & $\begin{array}{l}0.87 \pm 0.03 \\
0.023 \pm 0.002\end{array}$ & $0.026 \pm 0.003$ & $0.85 \pm 0.003$ & \\
\hline
\end{tabular}

Number of replicates $=3$

Besides the modifier $\mathrm{NH}_{4} \mathrm{H}_{2} \mathrm{PO}_{4}$, three other modifiers were investigated for use with beer samples, $\mathrm{NH}_{4} \mathrm{H}_{2} \mathrm{PO}_{4}+$ $\mathrm{Mg}\left(\mathrm{NO}_{3}\right)_{2}, \mathrm{Pd}, \mathrm{Pd}+\mathrm{Mg}\left(\mathrm{NO}_{3}\right)_{2}$ as they had been used in analyses of foods and beverages in general $[4,6]$ and specifically for beer [3]. None yielded as good results as $\mathrm{NH}_{4} \mathrm{H}_{2} \mathrm{PO}_{4}$ and as a consequence this modifier was the one chosen for the present work.

The beers analysed $(\mathrm{n}=62)$ contained $\mathrm{Pb}$ concentrations ranging from not detected to $290 \mu \mathrm{g} / \mathrm{L}$ and the $\mathrm{Cd}$ concentrations varied from not detected to $14.3 \mu \mathrm{g} / \mathrm{L}$. The averages were $38 \mu \mathrm{gPb} / \mathrm{L}$ and $1.6 \mu \mathrm{gCd} / \mathrm{L}$.
The concentrations of $\mathrm{Pb}$ and $\mathrm{Cd}$ in the samples studied (Table 2) were all below the limit for alcoholic beverages established by Brazilian Ministry of Health, $0.5 \mathrm{mg} / \mathrm{L}$ for both elements [2]. The levels found for lead are low and should not be cause of concern. The values found for cadmium can be considered negligible. Previous work with Brazilian beers $(\mathrm{n}=18)$ found $\mathrm{Pb}$ concentrations ranging from 13 to $52 \mu \mathrm{g} / \mathrm{L}$ [8]. In comparison, the average lead concentrations in beers $(n=9)$ produced and consumed in Finland, was reported as $9 \mu \mathrm{g} / \mathrm{L}$ and the cadmium concentrations were bellow $1 \mu \mathrm{g} / \mathrm{L}$ [13]. In United Kingdom, the analyses of 302 samples of beer indicated a range of less than $10 \mu \mathrm{g} \mathrm{Pb} / \mathrm{L}$ to over $200 \mu \mathrm{gPb} /$ L [12]. Spanish beers $(n=8)$ have shown values from 3 to $15 \mu \mathrm{gPb} / \mathrm{L}$ [1] and Italian beers $(n=7)$ from less than 30 to $120 \mu \mathrm{gPb} / \mathrm{L}[5]$.

The concentrations of $\mathrm{Pb}$ and $\mathrm{Cd}$ of dark beers differed significantly from light beers at $1 \%$ and $5 \%$ level by the t-test (Table 4). The beer color is defined mostly by the kilning of the malt. Although the levels of lead and cadmium found do not represent any danger for the health of the general consumer it seems advisable to check which step of beer production is really causing an increase in the content of these elements.

No significant difference was found between the beers produced in predominantly rural areas and the ones 
produced in industrialized areas. These results come as good news if one considers that the main constituent of beer is actually water and some of the beers examined came from heavily industrialized areas. On the other hand, not surprisingly, the packaging did not exerted influence in the $\mathrm{Pb}$ or $\mathrm{Cd}$ content of the beers. In this case it can be reasoned that both types of packaging would not leach out significant quantities of $\mathrm{Pb}$ and $\mathrm{Cd}$ since these elements are not part of their composition (Table 4).

TABLE 4. Concentrations means, standard deviations, and results of testing for significant differences between groups of beer samples.

\begin{tabular}{|c|c|c|c|}
\hline Sample type & Number of samples & $\mathrm{Pb}(\mu \mathrm{g} / \mathrm{L})^{*}$ & $\mathrm{Cd}(\mu \mathrm{g} / \mathrm{L})^{*}$ \\
\hline $\begin{array}{l}\text { Rural } \\
\text { Industrial }\end{array}$ & $\begin{array}{l}36 \\
27\end{array}$ & $\begin{array}{l}32 \pm 43^{a} \\
44 \pm 71^{a}\end{array}$ & $\begin{array}{l}1.4 \pm 2.8^{\mathrm{a}} \\
1.8 \pm 2.9^{\mathrm{a}}\end{array}$ \\
\hline Light & 46 & $33 \pm 56^{a}$ & $1.0 \pm 2.3^{\mathrm{a}}$ \\
\hline Dark & 17 & $50 \pm 58^{b}$ & $3.1 \pm 3.6^{\mathrm{b}}$ \\
\hline $\begin{array}{l}\text { Aluminum can } \\
\text { Glass bottle }\end{array}$ & $\begin{array}{l}21 \\
42\end{array}$ & $\begin{array}{l}47 \pm 65^{\mathrm{a}} \\
32 \pm 52^{\mathrm{a}}\end{array}$ & $\begin{array}{l}1.4 \pm 1.4^{\mathrm{a}} \\
1.7 \pm 3.3^{\mathrm{a}}\end{array}$ \\
\hline
\end{tabular}

\section{4 - CONCLUSIONS}

Beer samples from 6 Brazilian states (Minas Gerais, Pará, Paraná, Rio de Janeiro, Rio Grande do Sul and São Paulo) were analysed for their cadmium and lead content. The concentrations of $\mathrm{Pb}$ and $\mathrm{Cd}$ were all below the limits set by the Brazilian Ministry of Health for these contaminants in alcoholic beverages. No significant difference was found between the beers produced in predominantly rural areas and the ones produced in industrialized areas. Beers packed in glass bottles and in aluminium cans also did not show significant difference in their $\mathrm{Pb}$ and $\mathrm{Cd}$ contents. The concentrations of $\mathrm{Pb}$ and $\mathrm{Cd}$ of dark beers were slightly higher and differed significantly from light beers.

\section{5 - REFERENCES}

[1] BIURRUM, M.C.Y., DOPAZO, M.C.G., BARRERA, M.P.B., BARRERA, A.B. Determinacion de plomo en cerveza por espectrometria de absorcion atomica con atomizacion electrotermica. Alimentaria, p.59-62, 1991.

[2] BRASIL. Ministério da Saúde. Decreto 55.871/65 de 26/03/ 65. In: Compêndio da Legislação de Alimentos - Consolidação das Normas e Padrões de Alimentos, Vol. I (Atos do Ministério da Saúde), Revisão $\mathrm{n} .7$, Associação Brasileira das Indústrias de Alimentos, São Paulo, 1999.

[3] DONHAUsER, W., WAGNER, D., JACOB, F. Kritische Spurenelemente in der Brauereitechnologie. Monatsschrift für Brauwissenschaft , V. 6, P. 247 - 256, 1987.

[4] ELLEN, G, VAN LOON, J.W. Determination of cadmium and lead in foods by graphite furnace atomic absorption spectrometry with Zeeman background correction: Test with certified reference materials. Food Additives and Contaminants, v. 7, p. $265-273,1990$.

[5] FINOLI, C., VECCHIO, A., VOLONTERIO, G., GIGLIOTTI, C. Elementi in tracce e radiottività in malti, luppoli e birre. Industrie delle Bevande, v. 19, p. 1-5, 1990.

[6] GARRICK, G., SCHLEMMER, G., SLAVIN, W. Matrix modifiers: Their role and history for furnace AAS. American Laboratory , v. 23, p. 120 - 131, 1991

[7] INSTITUTO BRASILEIRO DE GEOGRAFIA E ESTATÍSTICA. Pesquisa de Orçamentos familiares. 1996. http:// www.sidra.ibge.gov.br, 04/03/2002.

[8] MATSUSHIGE, I., OLIVEIRA, E. Determination of trace elements in Brazilian beers by ICP-AES. Food Chemistry, v.47, p. 205-217, 1993.

[9] MÜlleR, M., ANKE, M., ILliNG-GÜNTHER, H., THIEL, C. Oral cadmium exposure of adults in Germany. 2: Market basket calculations. Food Additives and Contaminants, v. 15 , p. $135-141,1998$.

[10] ORGANIZAÇÃO MUNDIAL DE SAÚDE. Elementos traço na nutrição e saúde humanas. Editora Roca, São Paulo, 1998, 297 p.

[11] REILLY, C. Metal contamination of food, Elsevier Applied Science, Londres, 1991, 284 p.

[12] SHERLOCK, J.C., PICKFORD, C.J., WHITE, G.F. Lead in alcoholic beverages. Food Additives and Contaminants, v.3, p. 347-354, 1986.

[13] TAHVONEN, R. Lead and cadmium in beverages consumed in Finland. Food Additives and Contaminants, v. 15, p. 446-450, 1998.

\section{6 - ACKNOWLEDGEMENT}

The second author, A.M.M.M., thanks the Conselho Nacional de Desenvolvimento Científico e Tecnológico $(\mathrm{CNPq})$ for the undergraduate grant (Bolsa de iniciação cientifica) that made possible her participation in the present work. 